\title{
Variation of the Gas Formation Regions within a Cigarette Combustion Coal during the Smoking Cycle*
}

\author{
by Richard R. Baker \\ Group Research and Development Centre, British-American Tobacco Co. Ltd., \\ Southampton, England
}

\section{INTRODUCTION}

In order to gain an insight into the mechanisms by which substances are formed inside a burning cigarette, it is essential to know the environmental conditions at their point of formation. In a previous study $(1,2)$, contour distributions of low molecular weight gases were obtained inside a burning cigarette under continuous draw conditions. These distributions were relatively easy to obtain since, to a first approximation, they did not change when they moved down the cigarette as the cigarette burnt under the steady conditions. The situation of intermittent puffing and smouldering is more complex since the gas distributions ate likely to change rapidly during the smoking regime, as is observed for the temperature distributions (3). Two studies $(4,5)$ have measured gas concentrations on the central axis of a burning cigarette during a puff. However, both studies extracted the gases from the cigarette during the whole puff, and thus obtained an average value for the internal concentrations which gave no indication of how they might vary during the puff.

The previous studies have shown that the interior of the coal is oxygen deficient, and have identified the general areas where the oxides of carbon are produced. Improved techniques are necessary to determine the rapid danges that occur in the gas concentration contours during the puff. Much larger quantities of data are needed for analysis than are required during continuous draw conditions; the transit time of the gases from the combustion coal of the cigarette to the gas analysis system can become particularly significant during a two-second puff, consequently the transit time must be kept as small as possible, and its effects corrected for.

A suitable experimental system for obtaining samples of gases from a cigarette coal at various times during a puff has been developed, together with computer programs for converting the data into a form suitable for computer plotting. The use of this system to obtain contour distributions of low molecular weight gases inside the coal at various times during puffing and smouldering is described in this paper.

- Receired: 10th June 1980 - accepted: 24th September 1980.

\section{EXPERIMENTAL DETAILS}

The experimental system consisted of a sampling probe inserted radially into the cigarette, and connected via a small filtration unit to a quadrupole mass spectrometer. The dimensions of the sampling system have been kept as small as possible, compatible with there being no blocking by tarry material produced by the burning cigarette. The cigarette was smoked in an atmosphere of $21 \%(\mathrm{v} / \mathrm{v})$ oxygen in argon, so that the product carbon monoxide could be monitored mass spectrometrically at the $\mathrm{m} / \mathrm{e} 28$ peak, without interference from atmospheric nitrogen.

Untipped cigarettes were used in the study, containing a typically English-type flue-cured tobacco, cut at 56 cuts per inch. The cigarettes were $70 \mathrm{~mm}$ long, $8 \mathrm{~mm}$ in diameter, and were wrapped in naturally porous paper of air permeability $18 \mathrm{~cm} \mathrm{~min}^{-1}\left(10 \mathrm{~cm} \text { water }{ }^{*-1}\right)^{-1}$. The cigarettes were selected for weight $(0.99 \pm 0.02 \mathrm{~g})$ and pressure drop $(9.3 \pm 0.5 \mathrm{~cm}$ water at an air flow of $17.5 \mathrm{~cm}^{3} \mathrm{~s}^{-1}$ ), and were conditioned at $21^{\circ} \mathrm{C}$ and $60 \%$ relative humidity.

\section{The Probe Assembly}

The probe was constructed from a quartz tube $90 \mathrm{~mm}$ long, $1.1 \mathrm{~mm}$ outside diameter and $0.95 \mathrm{~mm}$ inside diameter. Inside the quartz tube, a platinum and platinum - $13 \%$ rhodium thermocouple junction $(0.05 \mathrm{~mm}$ diameter wire) was mounted at the end which would be inserted into the cigarette, with both of the thermocouple leads threaded through $0.2 \mathrm{~mm}$ outside diameter quartz tubing. A stainless steel tube $(0.31 \mathrm{~mm}$ inside diameter, $0.56 \mathrm{~mm}$ outside diameter) was also positioned inside the larger quartz tube, with its end $6 \mathrm{~mm}$ behind the cigarette end of the quartz. The other end of the steel tube protrubed $15 \mathrm{~mm}$ out of the quartz, and was connected to the filtration unit. The cold end of the quartz tube was sealed to the steel tube with epoxy resin.

The platinum and platinum-13\% rhodium thermocouple leads were connected using copper $-0.6 \%$ nickel and copper thermocouple compensating wire respectively, to a cold junction compensation unit (Churchill Instruments Co. Ltd., RJX 1/3B-L2).

\footnotetext{
*4 $1 \mathrm{~cm}$ water $=98 \mathrm{~N} \mathrm{~m}^{-2}$.
} 


\section{Filtration Unit}

The filtration unit consisted of a Cambridge filter pad (1 $\mathrm{mm}$ thick) positioned within two polytetrafluorethylene washers ( $7 \mathrm{~mm}$ inside diameter) and two rubber ' $\mathrm{O}$ ' rings (19 mm outside diameter, $4 \mathrm{~mm}$ thid) between two brass plates. Each brass plate had a $0.25 \mathrm{~mm}$ diameter hole drilled through its centre, through which the gas stream passed, and the two plates were held together with three nuts and bolts. The total volume between the two brass plates was $0.038 \mathrm{~cm}^{3}$ when they were bolted together, and it was filled entirely by the filter pad.

The exit side of the filtration unit was connected to the mass spectrometer via $1 \mathrm{~m}$ of $0.25 \mathrm{~mm}$ inside diameter stainless steel tubing. The flow $\left(0.12 \mathrm{~cm}^{3} \mathrm{~s}^{-1}\right)$ through the probe and filtration unit was governed by the impedance of this capillary tube connection to the mass spectrometer.

\section{Mass Spectrometer}

A Finnigan 400 quadrupole mass spectrometer was used, and a portion of the gases flowing down the capillary tube entered the ionisation chamber through a differentially pumped $25 \mu \mathrm{m}$ diameter orifice. The mass spectrometer was used in conjunction with an eight-channel peak selector (Finnigan Model 400-280-02) which can scan up to eight selected peaks in the mass spectrum of the sampled gases at a scan rate of $7.5 \mathrm{~ms}$ per channel, giving a quasi-continuous output for the intensity of each selected peak. Five peaks were monitored in the low resolution mass spectrum of the product gases, at $\mathrm{m} / \mathrm{e}$ values of $2,28,32,43$ and 44 . These peaks are due predominantly to the singly charged ions $\mathrm{H}_{2}^{+}, \mathrm{CO}^{+}, \mathrm{O}_{2}^{+}, \mathrm{C}_{3} \mathrm{H}_{7}{ }^{+}$and $\mathrm{CO}_{2}{ }^{+}$ respectively. The peaks at $\mathrm{m} / \mathrm{e}$ values 2,32 and 44 can accurately be used to monitor the concentrations of hydrogen, oxygen and carbon dioxide respectively, the maximum contributions from other components in the smoke being less than $1 \%$ in all cases (1). However, the peaks at $\mathrm{m} / \mathrm{e}$ values 28 and 43 are formed from more than one component. Thus, $\mathrm{m} / \mathrm{e}=28$ is due to $\mathrm{CO}^{+}$from carbon monoxide and a small contribution from carbon dioxide, as well as $\mathrm{C}_{2} \mathrm{H}_{4}{ }^{+}$from ethylene, while $\mathrm{m} / \mathrm{e}=43$ is due to $\mathrm{C}_{3} \mathrm{H}_{7}{ }^{+}$from propane and higher hydrocarbons, and $\mathrm{C}_{2} \mathrm{H}_{3} \mathrm{O}^{+}$from acetaldehyde and methyl ketones. The concentration of carbon monoxide was therefore obtained by solving the simultaneous equations for concentrations and intensities of the multi-component peak at $\mathrm{m} / \mathrm{e}=28$, in a similar manner to that described previously (1). The peak at $\mathrm{m} / \mathrm{e}$ value 43 was used uncorrected to obtain the concentration of propane, and the resultant concentrations may be too high by up to $25 \%$.

The five mass spectrometric peaks, together with the output from the thermocouple mounted in the sampling probe, were monitored on a multi-channel data logging system built of CAMAC data-handling modules (Nuclear Enterprises L.td.).

\section{Smoking Details}

The cigarette was smoked in an atmosphere of $21 \%(\mathrm{v} / \mathrm{v})$ oxygen $/ 79 \%(v / v)$ argon inside a hollow perspex cube of $140 \mathrm{~mm}$ side. The oxygen/argon mixture entered the cube at the bottom and left at the top, both via $112 \mathrm{~mm}$ diameter conical filter funnels. The lower filter funnel was loosely packed with glass wool to enhance smooth flow past the cigarette. The cigarette was smoked horizontally in the centre of the chamber, and was lit by a small, movable electrically heated wire, positioned inside the chamber. The sampling probe entered the chamber horizontally via a rubber septum, and entered the cigarette radially.

The gas mixture was passed vertically through the chamber at a flow rate of $250 \mathrm{~cm}^{3} \mathrm{~s}^{-1}$, equivalent to a linear velocity of $12.8 \mathrm{~mm} \mathrm{~s}^{-1}$ or 0.18 miles per hour past the cigarette. 'This is equivalent to a Beaufort force 0 air condition, i.e. "calm air" (6).

The cigarettes were smoked singly in the smoking chamber using a Cigarette Components Ltd. C.S.M. 10 smoking machine, taking a $35 \mathrm{~cm}^{3}$ puff of $2 s$ duration, once per minute under restricted smoulder conditions. The pressure-time profile of the puff was square.

The CSM 10 was modified so that while operating automatically on a given smoking regime, the puffing cycle could also be manually started at any point by actuating the puff cycle relays of the smoking machine. A parallel push-button switch device was used, such that one switch triggered a monostable and produced an impulse for the CAMAC system to change the data scanning frequency, while the other switch initiated a new puffing cycle on the smoking madine.

\section{Experimental Procedure}

For a given position of the probe in the cigarette, at least four replicate experiments were performed. The mass spectrometer was systematically calibrated before each replicate experiment, using known gas mixtures.

A reference mark was placed on the cigarette, $12 \mathrm{~mm}$ from the end to be lighted. The cigarette was positioned inside the smoking chamber and the probe was inserted radially into the cigarette at the required distance from the reference mark, and to the required distance from the central axis. The hole in the cigarette paper was sealed with a minimum amount of latex solution, and the solution allowed to dry. When the $21 \%(\mathrm{v} / \mathrm{v})$ oxygen in argon gas mixture had flowed through the chamber sufficiently long so that all traces of air were removed, the cigarette was lit with the electrically heated wire, and the cigarette smoked automatically for the first two puffing cycles. During the smoulder period prior to the thitd puff the CAMAC data logging system was initiated, taking 1 reading every five seconds. When the smouldering burn line reached the reference mark on the cigarette, the parallel push-button switch was depressed and the third puff started, and the CAMAC system commenced taking two six-channel scans of readings per second. Slight variation from experiment to experiment in the smoulder burn rate and the length of tobacco rod burnt in each puff, gave the smoulder period prior to the third puff a duration of between 55 and 65 seconds. Data logging continued for about one minute after the end of the puff. A location 
change on the punched paper tape print-out from the data logger indicated when the puff had started.

In successive experiments, the probe was inserted into the cigarette for distances of $0,1,2,3$ and $3.5 \mathrm{~mm}$ from the central axis, and at distances of between -10 and $+10 \mathrm{~mm}$ from the line of paper burn at the start of the third puff (Table 1).

Tabie 1. Initial positions of probe for the internal contour detorminations.*

\begin{tabular}{c|cccccccccc}
\hline $\begin{array}{c}\text { Distance from } \\
\text { central axis } \\
\text { of cigarette } \\
\text { (mm) }\end{array}$ & \multicolumn{6}{c}{$\begin{array}{c}\text { Initial * axial distance (mm) } \\
\text { from paper burn line }\end{array}$} \\
\hline 0 & -10 & -6 & -4 & -2 & 0 & 2 & 4 & 6 & 8 & 10 \\
1 & -10 & -6 & -4 & -2 & 0 & 2 & 4 & 6 & 8 & \\
2 & -10 & -6 & -4 & -2 & 0 & 2 & 4 & 6 & 8 & \\
3 & -10 & -6 & -4 & -2 & 0 & 2 & 4 & 6 & \\
3.5 & -10 & -6 & -4 & -2 & 0 & 2 & 4 & & & \\
\hline
\end{tabular}

- Axial positione in the unburnt tobacco rod are given as negative distances from the line of paper burn, the burn line is given the axial poaltion of zero, and positions in the coal and ash are given as positive distances from the burn line.

* The distance at the start of the third puff in the smoking regime. During the puff, the paper burn line moves down the tobacco rod with a linear speed of $1.29 \mathrm{~mm} \mathrm{s-1}$. For about $15 \mathrm{~s}$ after the end of the putt, the paper burn line is stationary; it then moves with a mean linear speed of $0.069 \mathrm{~mm} \mathrm{~s}^{-1}$.

\section{Data Processing}

Preliminary calibration experiments showed that for all the gases determined, the peak intensity / gas concentration relationships were linear. The thermocouple e.m.f. / temperature relationship was quadratic.

The calibration and experimental data from the replicate experiments for each probe position, obtained on punched paper tape, were processed on an off-line computer to gas concentrations and temperature. The transit times of the gases to the mass spectrometer, and the changing position of the cigarette paper burn line relative to the probe, during smoulder and puffing, were both accounted for. The means of the replicates were calculated at each time interval during the smoking cycle, together with the variation at the $95 \%$ confidence limit. A second program converted the processed data from all the combined probe positions into a form suitable for plotting contours of temperature and gas concentrations at specified times during the smoking cycle. For subsequent mapping of contours, the distribution was taken as symmetrical about the central axis. The contour distributions were plotted on a Calcomp 925/1036 drum plotter, using a general purpose contour plotting program. Preliminary comparisons indicated that the computer plotted contour distributions were essentially the same as if the plots had been done manually.

\section{ASSESSMENT OF EXPERIMENTAL SYSTEM}

The flow rate of $250 \mathrm{~cm}^{8} \mathrm{~s}^{-1}$ through the smoking chamber of $140 \mathrm{~mm}$ side length was equivalent to a Reynolds number of 116 . Thus the flow conditions inside the cham- ber ought to be laminar. In confirmation of this, the sidestream smoke was observed to rise from the cigarette in a very straight column.

Using these flow conditions, the burn rates of the cigarette during the third puff, and in the smoulder period, were the same as when the cigarette was smoked in open air (1.29 and a mean $0.069 \mathrm{~mm} \mathrm{~s}^{-1}$ respectively). Furthermore, no decrease in the bulk concentration of oxygen in the smoking chamber could be detected as the cigarette smouldered, or when puffs were taken. The puff by puff carbon monoxide deliveries were effectively the same in the smoking chamber as when smoked in open air. Thus the presence of the smoking chamber should have no adverse effects on the results.

As explained above, the full sampling system through which the gases were withdrawn from inside the cigarette to the mass spectrometer consisted of a quartz probe inside the cigarette, a filtration unit, and a $1 \mathrm{~m}$ length of capillary tube to the mass spectrometer. With a flow rate of $0.12 \mathrm{~cm}^{3} \mathrm{~s}^{-1}$ through the sampling system, the gases travel through the capillary tube to the mass spectrometer in $0.4 \mathrm{~s}$, with the mean diffusional spreading less than $0.003 \mathrm{~s}^{*}$. The response of the full sampling system (probe + filtration unit + capillary tube) to a very fast ( $0.02 \mathrm{~s})$ change in gas concentration has been determined for the gases monitored in the study. The maximum differential response is obtained in $0.5 \mathrm{~s}$, but in this case diffusional spreading of $0.1 \mathrm{~s}$ occurs, largely in the filtration unit. However, when a $0.1 \mathrm{~s}$ concentration pulse of a known gas mixture travelled through the sampling system, $91 \%$ of the full concentrations were monitored at the mass spectrometer. For 0.5 and $1.0 \mathrm{~s}$ pulses, $97 \%$ and $99 \%$ of the full concentrations were monitored respectively. Thus, even the fastest concentration changes can be monitored with less than a $10 \%$ error in concentration. In subsequent calculations, a transit time of $0.5 \mathrm{~s}$ for the gases to travel from the cigarette to the mass spectrometer has been used.

\section{RESULTS}

An example of some of the gas concentration profiles* obtained before, during and following a 2-second puff, for one position of the probe inside the cigarette, is shown in Figure 1. The $95 \%$ confidence limits of each mean point (mean of four replicates) are also shown. These are

\footnotetext{
* The linear gas velocity through the $0.25 \mathrm{~mm}$ inside diameter capillary tube was $2240 \mathrm{~mm} \mathrm{~s}^{-1}$, so that the time (t) for the bulk gas to flow $1 \mathrm{~m}$ is $0.41 \mathrm{~s}$. In this time, the mean diffusional spreading $(\sigma, \mathrm{mm})$ of a gas of binary diffusion coefficient $D\left(\mathrm{~mm}^{2} \mathrm{~s}^{-1}\right)$ is given by the Einstein formula $\sigma=\sqrt{2 D_{t}}$ (7). Maximum diffusional spreading will occur for hydrogen in the argon mixture. Since $D$ for $\mathrm{H}_{2} / \mathrm{Ar}$ at room temperature is $83 \mathrm{~mm}^{2} \mathrm{~s}^{-1}(8), \sigma=8.2 \mathrm{~mm}$, which is equivalent to a mean diffusional spreading time of $0.0034 \mathrm{~s}$ in this gas flow.

+ Gas concentration profiles (e.g. those in Figure 1) show the gas concentration as a function of time from the start of the puff, or axia distance from the burn line, for a given initial position of the probe in the cigarette. Gas concentration contour distributions (e.g. those in Figures 2-9) are obtained from a combination of many profiles for different initial probe positions, and show the gas concentration distribution throughout the coal at a given instant of time in the smoking cycle.
} 
Flgure 1. Gas concentration (\% (v/v)) along central axls of cigarette: sampllng probe positloned at paper burn line at start of putt.




generally of the order of $\pm 10 \%$ of the mean values, but do depend on the quantity of gas and the position in the smoking cycle. For example, the oxygen concentration and its $95 \%$ confidence limit in the smoulder period at -17.5 seconds in Figure $1(\mathrm{a})$ is $9.2 \pm 0.8 \%(\mathrm{v} / \mathrm{v})$, whereas in the middle of the puff at +1.0 seconds it is $0.2 \pm 0.2 \%(\mathrm{v} / \mathrm{v})$. However, because of the steep concentration gradients involved in the contour diagrams (Figures 2 (b) to $9(\mathrm{~b})$ ), the oxygen-deficient region of the coal is still fairly accurately defined. These variations are due predominantly to slight variations in the cigarettes used, and the inability to mount the probe into identical environments inside the cigarette for each replicate experiment, rather than any variation in the mass spectrometric concentration determinations.

The $95 \%$ confidence limits of the mean temperatures are about $\pm 25^{\circ} \mathrm{C}$. Within the limits of this variability, the gas temperature and concentration distributions inside the cigarette are symmetrical about the central axis of the cigarette.

The contour distributions of temperature, oxygen, carbon monoxide, carbon dioxide, hydrogen and propane* inside the combustion coal of the cigarette, at various stages during and following the third puff are given in Figures
2-9. In these diagrams, serrated contours represent valleys. The sign convention of the axial distances used in these diagrams is defined in the first footnote to Table 1. Gas-phase temperature distributions have also been obtained in the present study using a thermocouple positioned at the end of the gas sampling probe. They were uncorrected for conduction effects along the probe, and were consequently substantially lower than those reported previously in a more definitive temperature study (3). Consequently, the gas-phase temperature distributions illustrated in Figures 2-9 are those obtained previously.

The changes that occur in the distributions during the smoking cycle (Figures 2-9) are complex, and reflect the complex interactions of chemical and physical processes that are occurring. When examining these diagrams, it must be borne in mind that they are highly averaged distributions, and that the variability limits can be fairly large. Thus details of the distributions within a given individual cigarette could be different to those illustrated. Furthermore, although the broad changes that occur in the distributions during the smoking cycle are distinct and significant, care should be exercised in assigning significance to the more erratic and highly localised changes.

The main features of these distributions are briefly summarised below, and are commented on further in the Discussion section.

The central regions of the coal, in front of the paper burn line, are almost entirely devoid of oxygen, and this deficiency remains unchanged throughout the smoking cycle. During the static smoulder period, distinct high and low temperature regions for the formation of carbon monoxide and dioxide are not evident inside the coal, as is observed when the cigarette is smoked at a continuous draw of $2.0 \mathrm{~cm}^{3} \mathrm{~s}^{-1}$ (1). Throughout the 2-second puff, the level of carbon dioxide in the region of the coal corresponding to the lowest oxygen levels falls continuously, and remains constant after the end of the puff. However, towards the latter half of the puff, a distinct carbon dioxide formation region behind the completely oxygendeficient region, and roughly at the position of the paper burn line, starts to appear. The levels in this region increase sharply for about two seconds immediately the puff ends, before falling again over about the next ten seconds.

The levels of carbon monoxide and hydrogen, both inside the coal and behind the coal, increase throughout the puff. Propane is formed in the coal on either side of the central axis, and its levels decrease throughout the puff. All the gas contours behind the coal are progressively drawn further towards the mouth end of the cigarette during the puff, and retract when the puff ends.

For all gases, when the puff ends the product formation/transmission balance is interrupted, resulting in a local build-up of the product in its formation region. The high concentrations extend right to the periphery of the

\footnotetext{
* Monitored on the mass spectrum peak at $\mathrm{m} / \mathrm{e}=43$, which is due mainly to the propyl radical, produced from propane and higher hydrocarbons. Propane was used to calibrate this peak.
} 


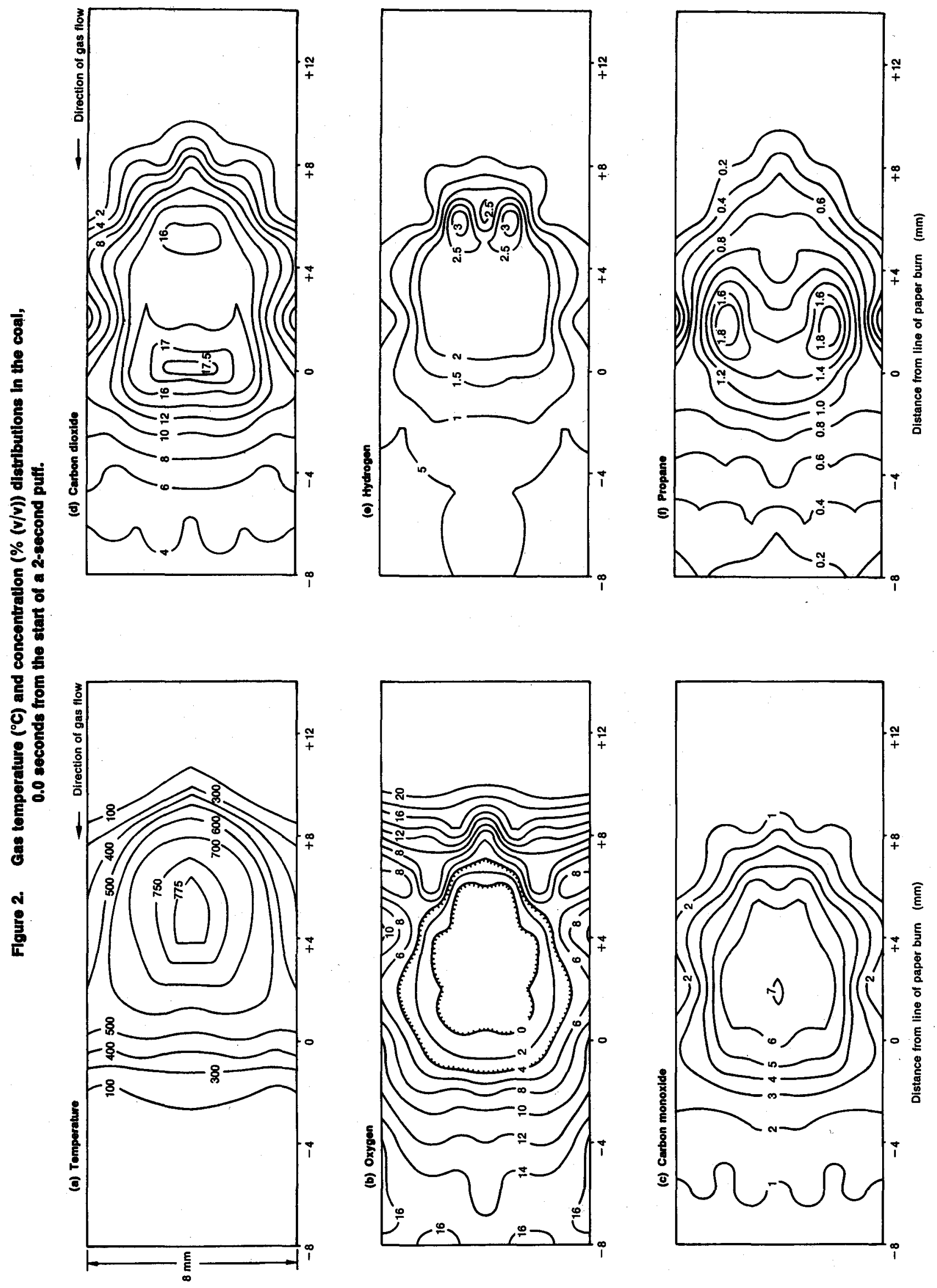




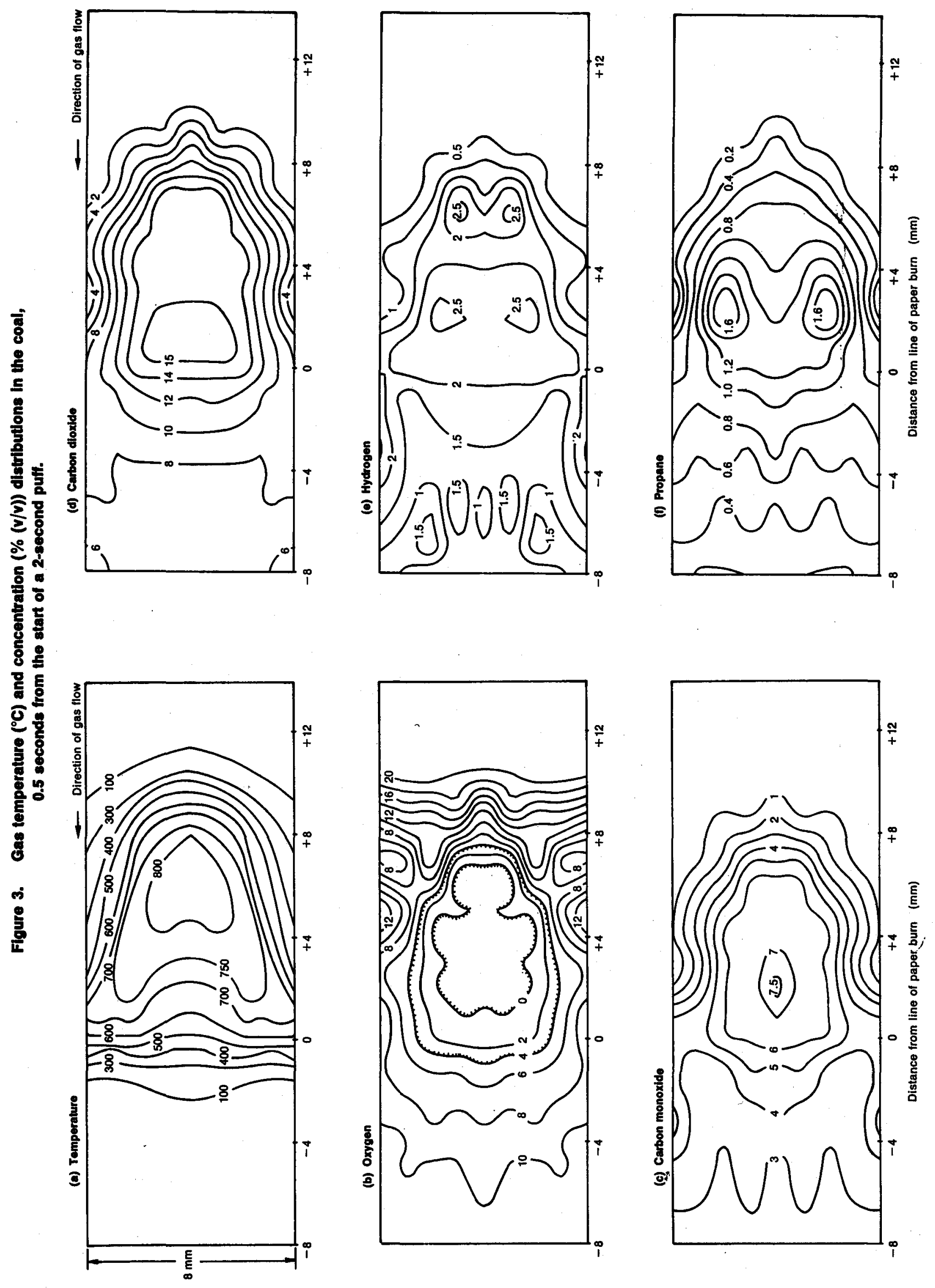




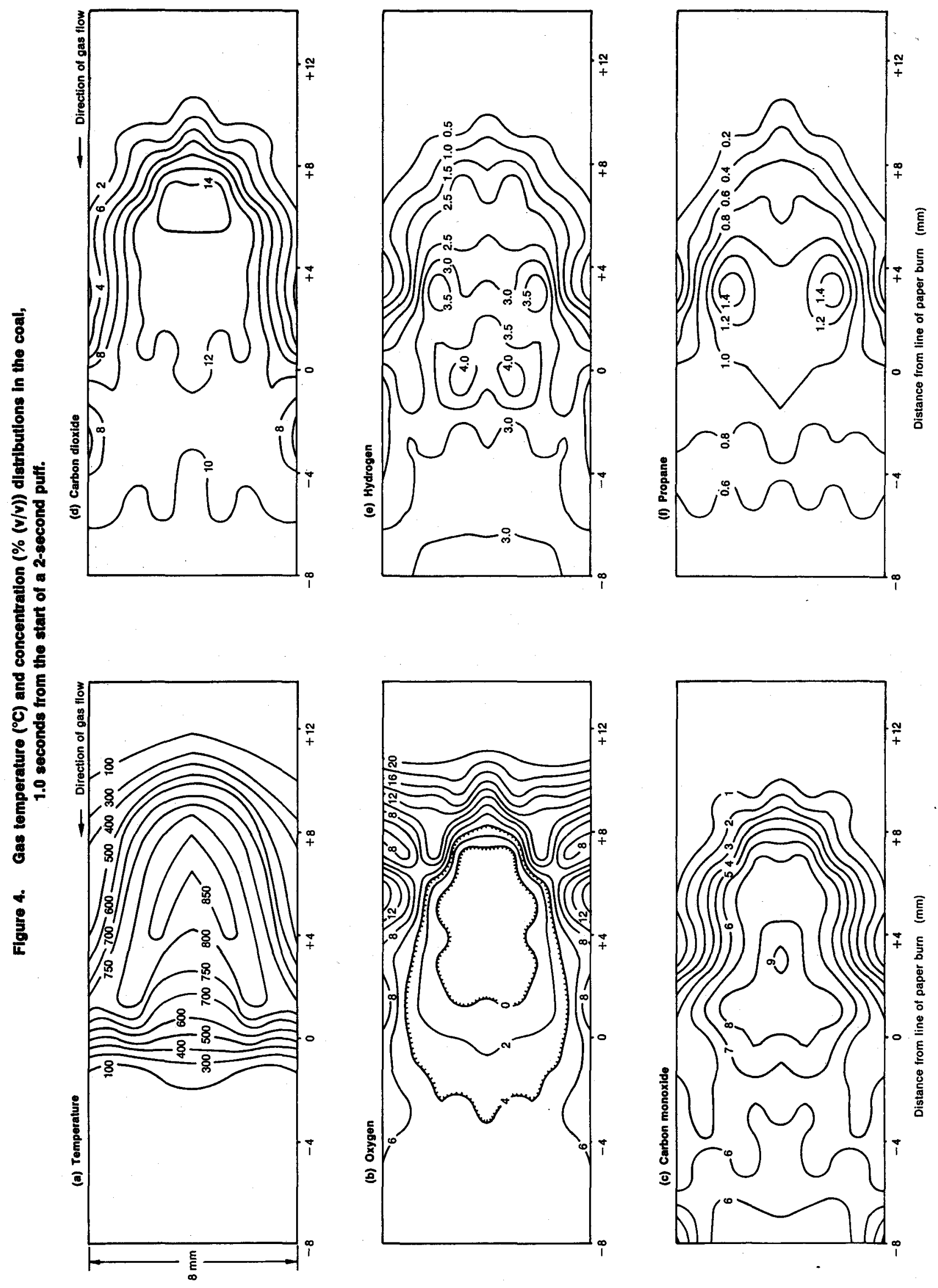



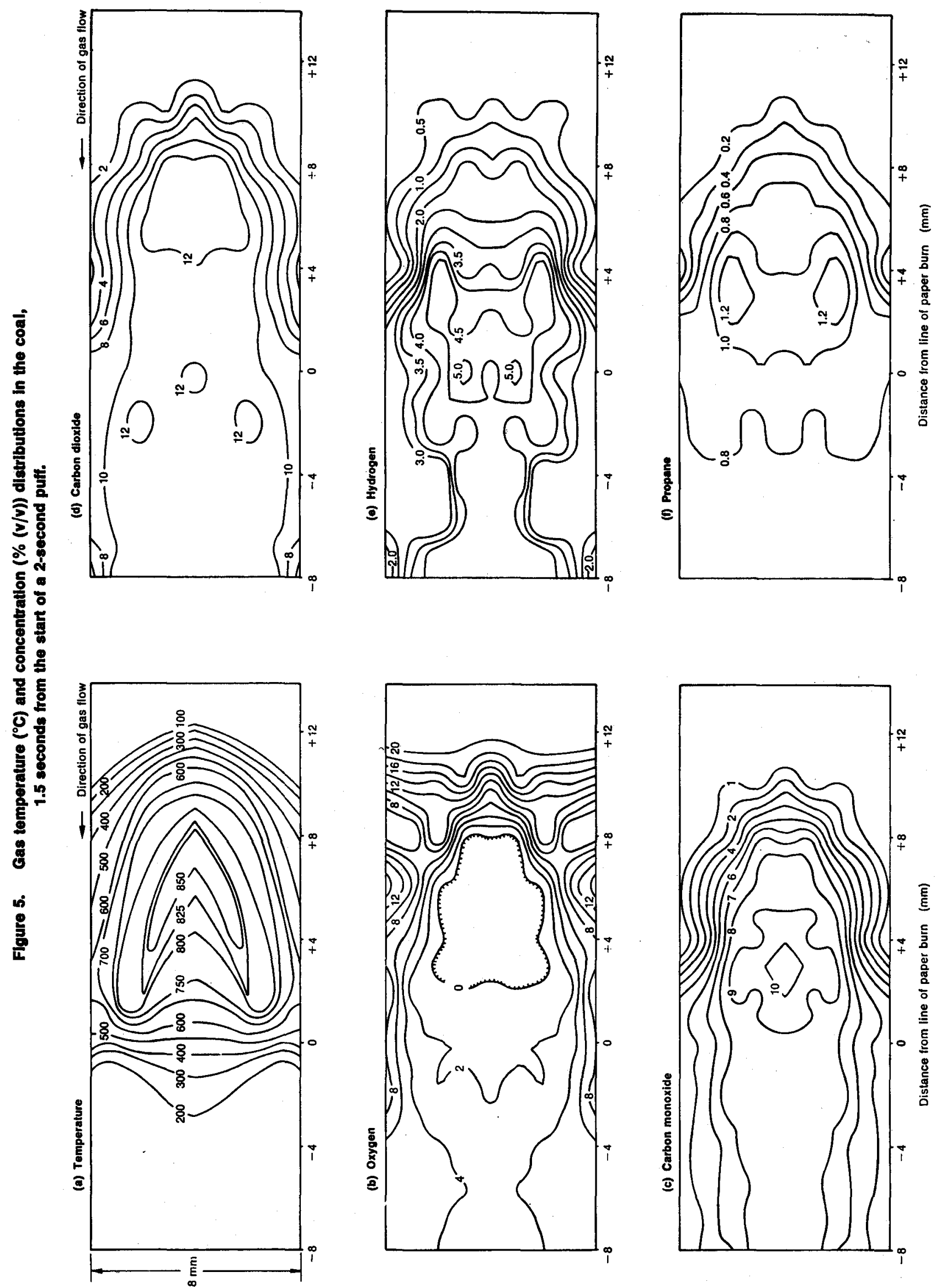

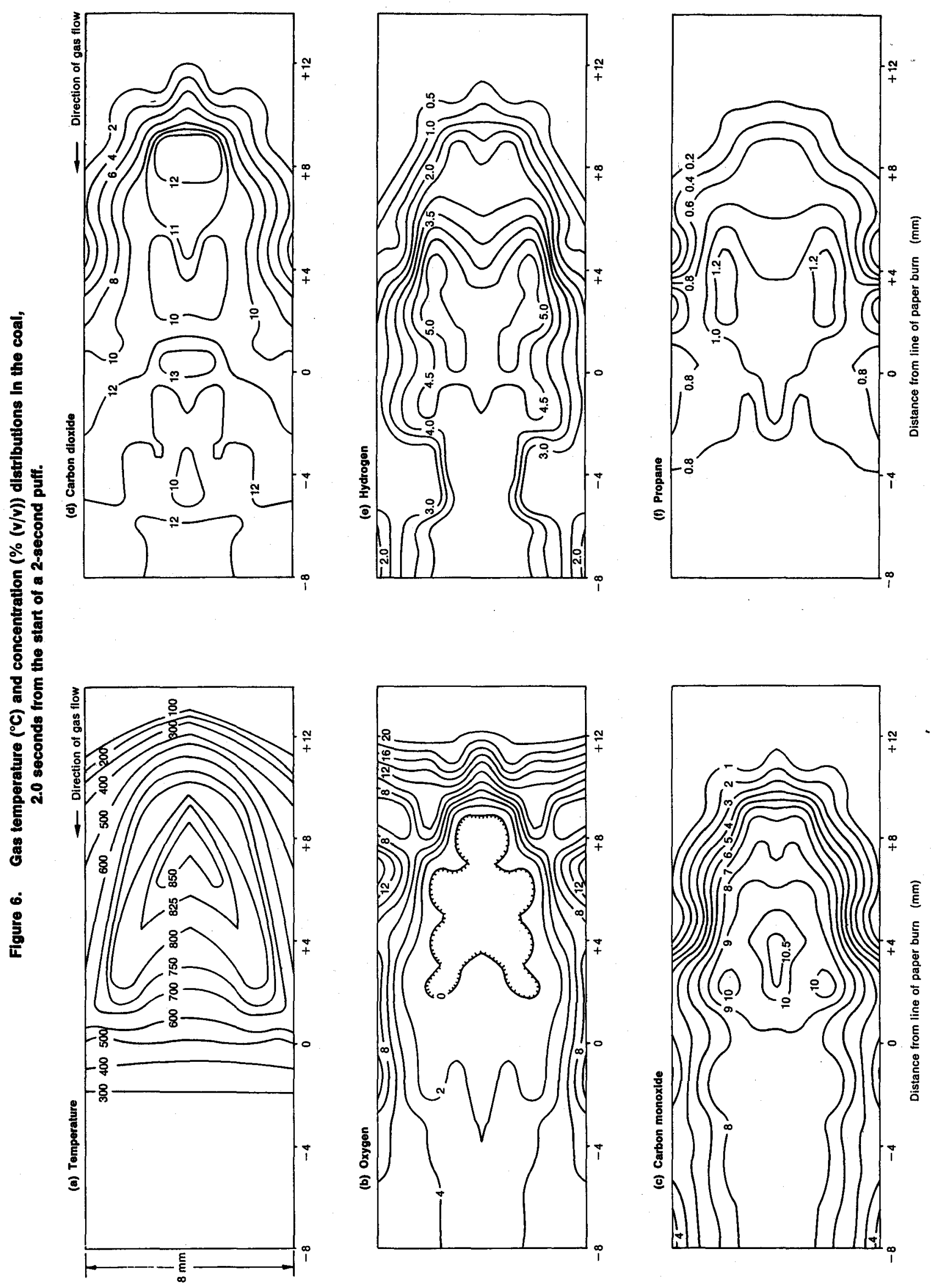


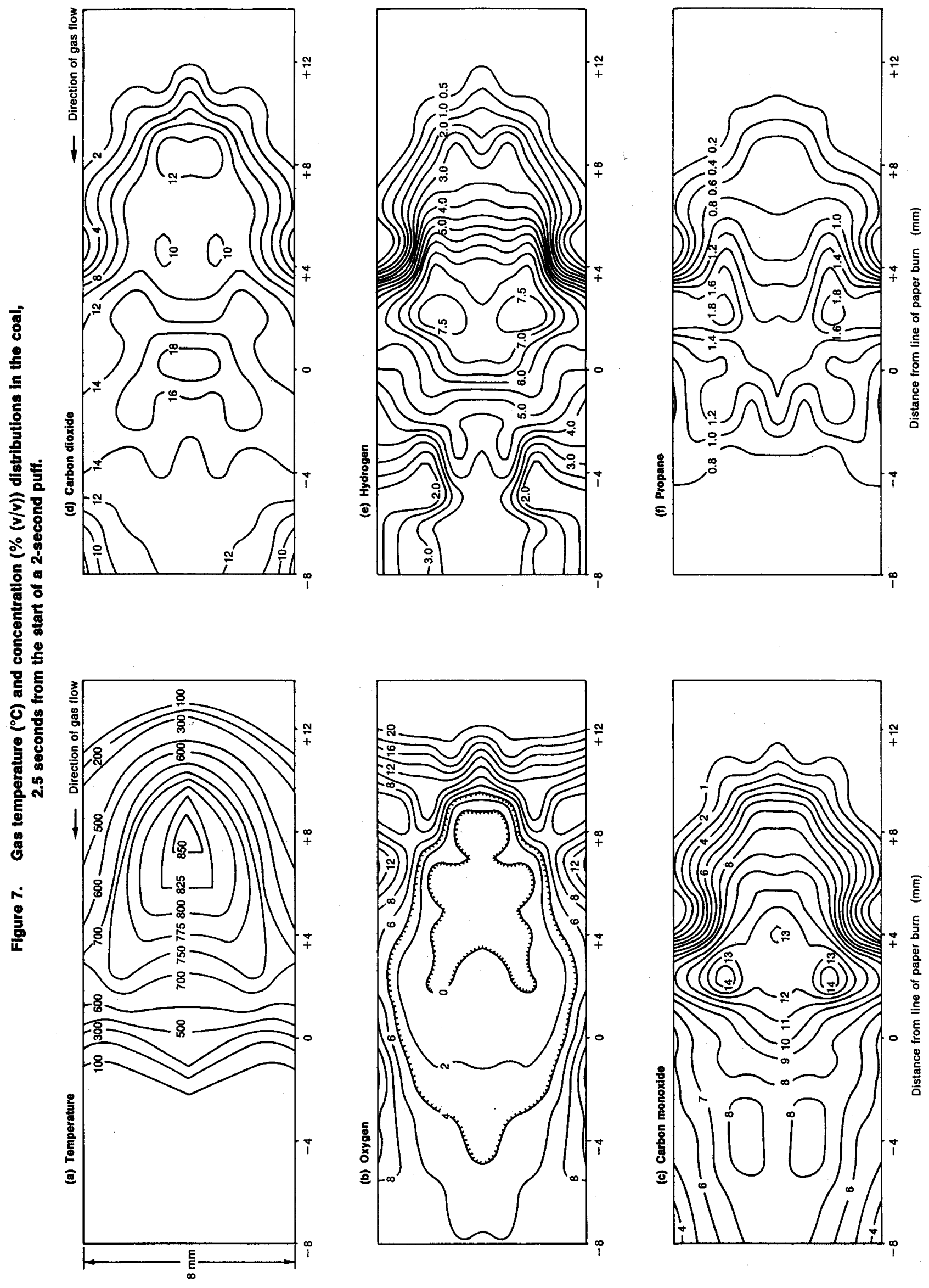



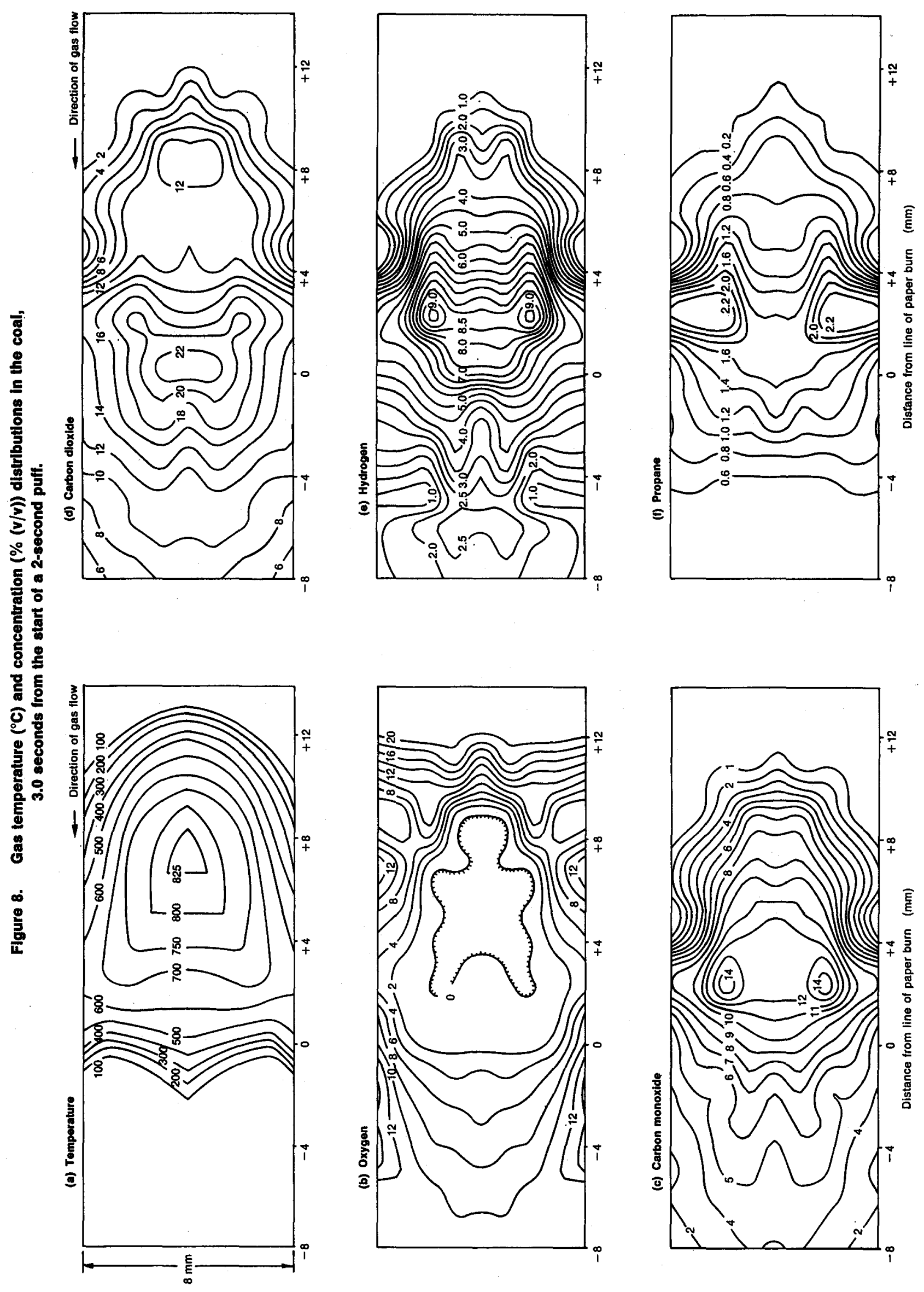

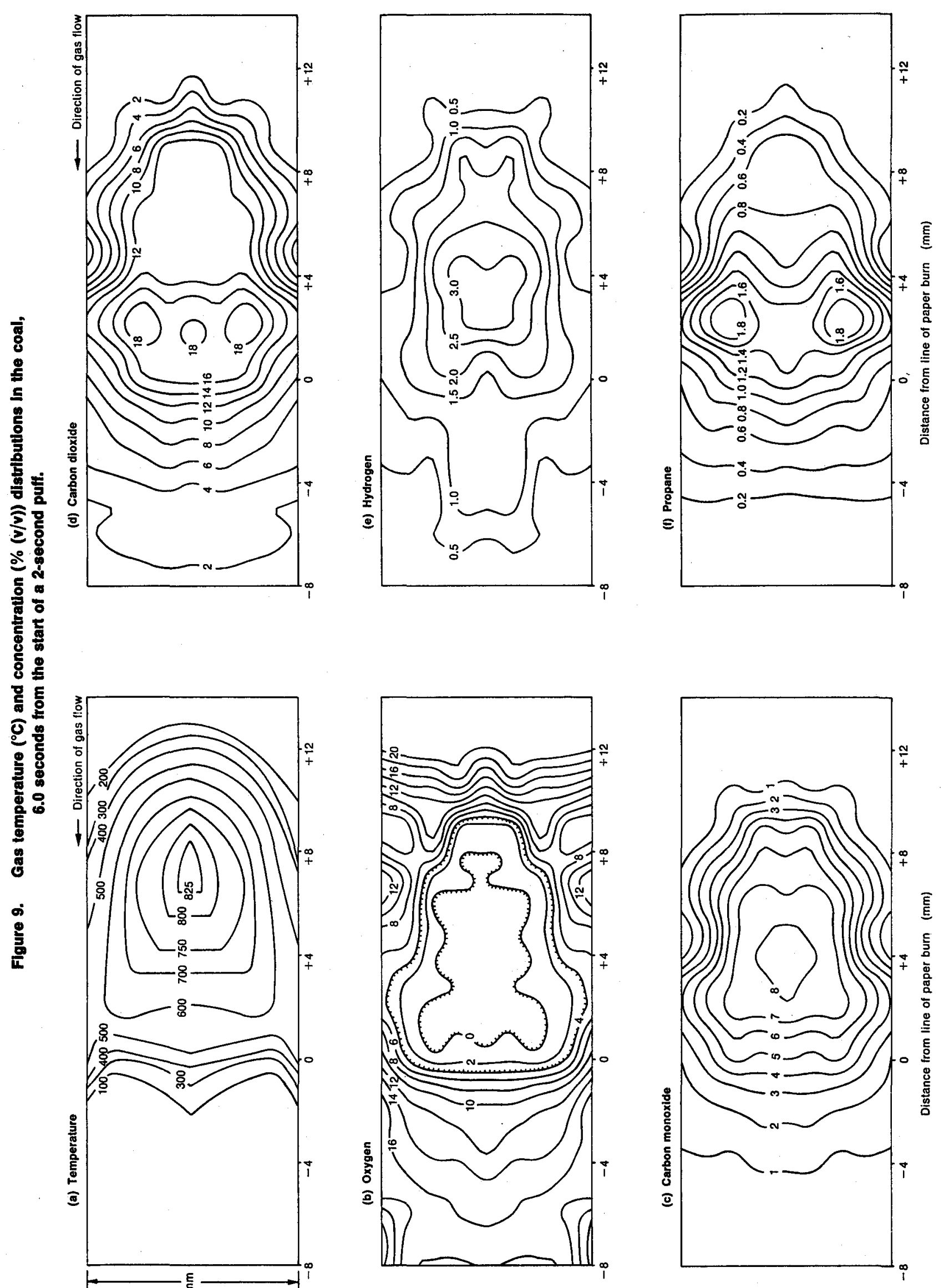
Figure 10. Variation with time of gas concentrations on central axis of cigarette, and $+3 \mathrm{~mm}$ from paper burn line.



coal, especially at about +2 to $+3 \mathrm{~mm}$ from the paper burn line. An examination of gas temperature and concentration distributions outside the cigarette $(9,10)$ suggests that this is the position where the sidestream permanent gases leave the coal. After about two seconds, diffusion processes have had time to deplete the local build-up, and within a further 10-15 seconds the contour distributions are virtually as they were before the puff.

The variations in concentration with time can be seen more clearly by following the variation at a specific point inside the coal. An example is shown in Figure 10, for a point on the central axis of the cigarette, and $+3 \mathrm{~mm}$ from the paper burn line. This point is not fixed in absolute space, since it moves as the cigarette burns. It always remains $3 \mathrm{~mm}$ in front of the paper burn line, and is thus a point which rides along on the combustion wave. The curves in Figure 10 illustrate that at this point both the hydrogen and carbon monoxide concentrations increase during the puff, while the carbon dioxide level falls, and the propane level is unaffected. The level of all gases increase when the puff ends, and they then gradually fall to the levels attained during smouldering before the puff.

Behind the burn line (Figure 11), the oxygen level drops sharply as the puff commences, decreases throughout the puff, and rises sharply once the puff has ended. Hydrogen and carbon monoxide both increase for the first $1.5 \mathrm{sec}-$ onds of the puff, then their levels remain stationary for the remainder of the puff and the first half second of smoulder, after which their levels fall. The carbon dioxide level increases sharply at the start of the puff, remains effectively constant during the puff, and increases for the first second after the cessation of the puff.

\section{DISCUSSION}

\section{Internal Oxygen Distribution}

The oxygen-deficient coal in the present puff/smoulder regime is only half the length of that obtained previously un-
Figure 11. Varlation with time of gas concentrations on central axls of cigarette, and $-2 \mathrm{~mm}$ from paper burn line.



der continuous draw conditions of $2.0 \mathrm{~cm}^{3} \mathrm{~s}^{-1}$ (1). Under continuous draw conditions the air entering the coal is more evenly distributed along the surface of the coal than during a puff, and the coal advances down the tobacco rod with a constant rate and with a fairly flat combustion front along the diameter of the cigarette. However, during a puff a much larger proportion of the incoming air enters the cigarette at the base of the coal, near the paper burn line $(3,11,12)$ causing the edge of the coal to burn down much more than the centre. During the interpuff smoulder the centre of the coal moves down faster than the edges and this process compensates for the change in shape of the coal induced during the puff. Thus the changing pattern of the advancing coal during intermittent puffing and smouldering does not allow it to achieve the length attained under a continuous draw.

Throughout the smoking cycle the oxygen contours in the central regions of the coal, in front of the paper burn line, remain virtually unchanged. Thus most of the incoming oxygen during the puff is consumed before it can reach the centre of the coal, even $8 \mathrm{~mm}$ in front of the burn line. There is no evidence, in any of the oxygen contour distributions during the puff, of any high spots of oxygen near the paper burn line, where a large proportion of the incoming air enters the coal. The rate of consumption of oxygen is therefore extremely rapid, confirming earlier conclusions $(13,14)$ that the rate of combustion of tobacco is controlled by the rate of oxygen transport to the tobacco surface. Furthermore, the incoming oxygen is consumed so rapidly that there are only slight indications for the existence of a cone-shaped oxygen-deficient region at the back of the coal. It is only near the periphery of the coal, at the point where the major influx of air and therefore combustion occurs, that there is any evidence of the incoming oxygen not being completely consumed. Since the rate of reaction of oxygen with tobacco is always much faster than the transport of oxygen to the tobacco, this effect must be due to the complete consumption of the reactant tobacco at this point. 
A close examination of the oxygen contours, both during the puff and the smoulder period, reveals that there are small regions of relatively high oxygen concentration on the surface of the coal. This region centres at about $+4 \mathrm{~mm}$ from the paper burn line before the puff (Figure $2(b)$ ), and gradually moves to centre at about $+7 \mathrm{~mm}$ during the puff, where its position remains constant in the post-puff distributions. Since the paper burn line travels down the tobacco rod at $1.29 \mathrm{~mm} \mathrm{~s}^{-1}$ during the puff, and remains stationary for 15-20 seconds after the puff, the apparent movement of this oxygen high-spot is actually caused by the region remaining stationary in absolute space and the burn line moving away. Furthermore, since the paper burn line moved at a mean rate of $0.069 \mathrm{~mm} \mathrm{~s}^{-1}$ during the smoulder period, the position of the oxygen high spot of $+4 \mathrm{~mm}$ prior to the third puff in Figure 2(b) means that the spot would have been at the position of the paper burn line during the second puff in the smoking cycle. Consequently, the oxygen high spot must be the position at which air entered the coal in the preceding puff.Therefore, although the consumption of oxygen is so rapid that the position of its major influx into the coal cannot be seen during a puff, the oxygen influx does leave burnt-out channels in the coal, which become evident at later stages of the smoking cycle.

The region behind the coal rapidly becomes deficient in oxygen during the puff, and this deficiency is greatly reduced within 10-15 seconds of the puff's ending. The smoking conditions employed in the present study used restricted smoulder, so that the reduction in oxygen deficiency behind the coal must be due to inward diffusion via the paper. An examination of consecutive sets of oxygen contours after cessation of the puff suggests that much of the incoming oxygen influxes within about $6 \mathrm{~mm}$ behind the paper burn line.

\section{Combustion and Thermal Decomposition Regions Inside the Coal}

It is known that both carbon monoxide and carbon dioxide are formed by thermal decomposition and combustion of tobacco (15-18). However, inside the coal, under statically smouldering conditions, distinct high and low temperature regions for the formation of carbon monoxide and dioxide are not observed, in contrast to the situation under continuous draw conditions (1). The much shorter length of the coal under the present smoking regime has merged the two temperature regions. However, during the puff and post-puff smoulder, two distinct regions for carbon dioxide do emerge, although for carbon monoxide they remain virtually coalesced together over the whole smoking cycle. Throughout the puff, the level of carbon dioxide in the region of the coal corresponding to the lowest oxygen levels falls continuously, and remains level after the end of the puff. This is carbon dioxide formed mainly by combustion. However, towards the latter half of the puff, a distinct carbon dioxide formation region roughly at the position of the paper burn line starts to appear, and the levels in this region increase sharply for about two seconds immediately the puff ends.
This is carbon dioxide formed mainly by thermal decomposition of tobacco. These conclusions on the position of the two formation regions can be corroborated with the aid of the pyrolysis model developed previously (19) as follows.

For all gases, when the puff ends the product formation / forced convective transfer balance is interrupted, resulting in a local build-up of the product in its formation region. This local build-up reaches a maximum at 0.5-1.0 seconds after the end of the puff, after which time diffusion processes deplete the level. Thus, at 3.0 seconds from the start of the puff, the concentration contours define the formation regions of the products, with the minimum of interference from mass transfer effects. The contour distributions in Figure 8 thus show that carbon monoxide, hydrogen, and propane are formed in regions centering at $+2 \mathrm{~mm}$ from the paper burn line, while carbon dioxide formation centres at $+0.5 \mathrm{~mm}$. The observed axial profiles of carbon dioxide and carbon monoxide at 3.0 seconds are shown in Figures 12 and 13 respectively. Superimposed on these profiles is an axis for the gas phase temperatures in the coal. Just after the puff has ended, the tobacco in the coal is being heated at about $100^{\circ} \mathrm{C} \mathrm{s}^{-1}$ (3). Using the pyrolysis model and the kinetic parameters for formation of the gases deduced previously (19), the profiles for formation of carbon dioxide and carbon monoxide by thermal decomposition of tobacco at $100^{\circ} \mathrm{C} \mathrm{s}^{-1}$ can be predicted (also shown in Figures 12 and 13). For carbon dioxide (Figure 12), it is clear that the observed

Figure 12. Comparison of $\mathrm{CO}_{2}$ observed along central axis of clgarette at 3.0 seconds with that formed by thermal decomposition of tobacco at $100^{\circ} \mathrm{C} \mathrm{s}^{-1}$.

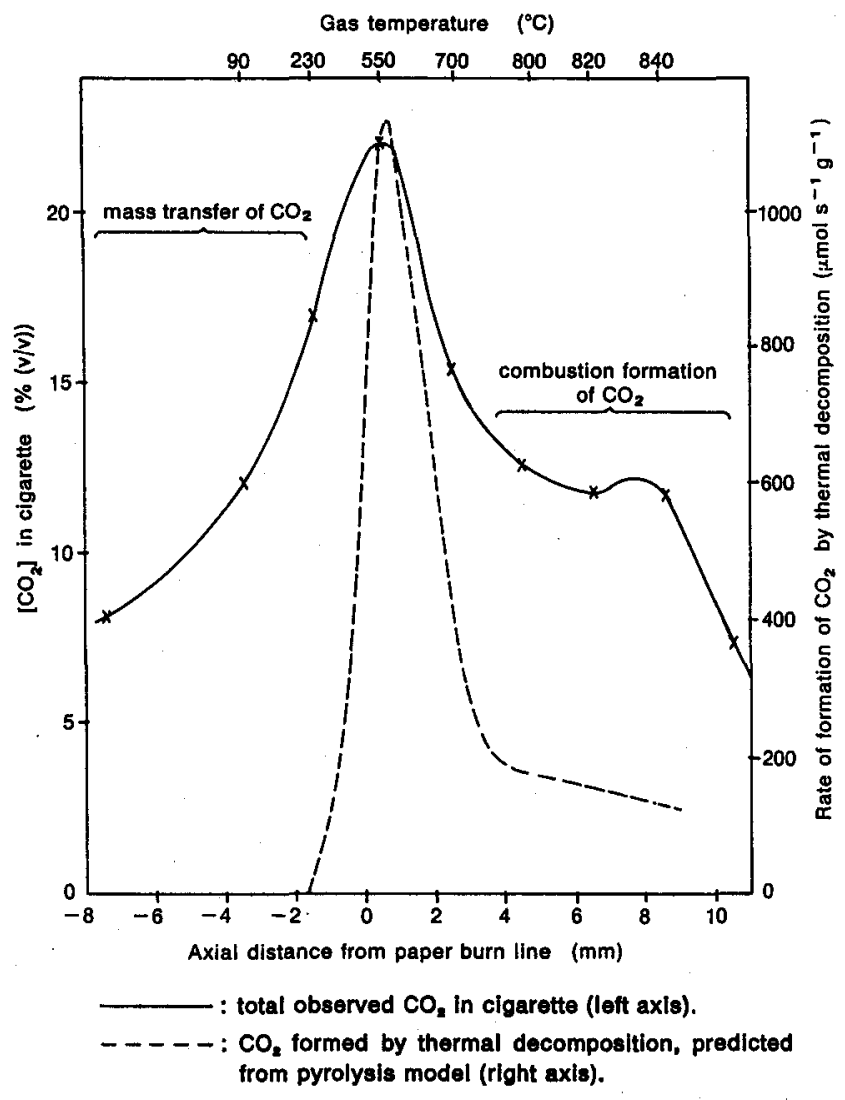


formation region centering at an axial position of $+0.5 \mathrm{~mm}$ from the paper burn line is formed by the thermal decomposition of tobacco. The formation region at $+8 \mathrm{~mm}$ must therefore be due to tobacco combustion. For carbon monoxide, on the other hand, see Figure 13, the thermal decomposition region is not resolved from the combustion region. Furthermore, at this heating rate, little of the high-temperature thermal decomposition carbon monoxide is evolved, as discussed previously (19).

The levels of carbon monoxide in all regions inside the coal increase throughout the puff (Figures 2 to 6,10 and 11). In the oxygen-deficient interior of the coal, this is accompanied by a decrease in carbon dioxide, and so could be due at least partly to the carbonaceous reduction of carbon dioxide to carbon monoxide. This reaction can be shown to proceed at an appreciable rate inside the coal, as follows.

Using results obtained previously (14), the rate of loss of carbon dioxide $\left(\mu \mathrm{mol} \mathrm{s}^{-1}\right)$ due to its reaction with tobacco to give carbon monoxide can be expressed as:

$$
\frac{-\mathrm{d}\left[\mathrm{CO}_{2}\right]}{\mathrm{dt}}=1.2 \times 10^{\circ}\left[\mathrm{CO}_{2}\right] \exp (-99,200 / \mathrm{RT}) \text {, }
$$

\section{where}

$\left[\mathrm{CO}_{2}\right]$ is concentration of carbon dioxide $\left(\mu \mathrm{mol} \mathrm{cm}{ }^{-3}\right)$,

$\mathrm{R}$ is the universal gas constant, $8.314 \mathrm{~J} \mathrm{~mol}^{-1} \mathrm{~K}^{-1}$,

and

$T$ is temperature (K).

For a large proportion of the puff, the mean concentration of carbon dioxide in the centre of the combustion coal is approximately $12 \%(\mathrm{v} / \mathrm{v})$ (Figures 3 to 6 ), the mean gas phase temperature is approximately $700^{\circ} \mathrm{C}$ and the mean solid phase temperature is approximately $750^{\circ} \mathrm{C} \mathrm{(3)}$. Thus, assuming ideal gas behaviour, this corresponds to a carbon dioxide concentration of $1.5 \mu \mathrm{mol}$ $\mathrm{cm}^{-3}$ inside the coal. Thus the rate of reduction of carbon dioxide is $5.7 \mu \mathrm{mol} \mathrm{s}^{-1}$ at $700^{\circ} \mathrm{C}$ (the gas phase tempera-

Figure 13. Comparison of co observed along central axis of clgarette at 3.0 seconds with that formed by thermal decomposition of tobacco at $100{ }^{\circ} \mathrm{C} \mathrm{s}^{-1}$.



: total observed co in cigarette (left axis).

- - - - : cO formed by thermal decomposition, predicted from pyrolysis model (right axis). ture) and $10.4 \mu \mathrm{mol} \mathrm{s}^{-1}$ at $750^{\circ} \mathrm{C}$ (the solid phase temperature). Clearly, both these rates are high compared with the concentration of available carbon dioxide.

\section{SUMMARY}

Internal contour distributions for gas temperatures and for the concentrations of carbon monoxide, carbon dioxide, hydrogen, propane and oxygen have been determined at successive times before, during and after a puff of a burning cigarette. The cigarette was smoked in an atmosphere of $21 \%(\mathrm{v} / \mathrm{v})$ oxygen in argon. The gases were withdrawn from the cigarette through a small sampling probe and filtration unit, and analysed using a quadrupole mass spectrometer.

The contour distributions show that the gas formation and transmission processes occurring in the coal, and their variation during the smoking regime, are complex. The interior of the coal is almost entirely devoid of oxygen. The consumption of oxygen is so rapid that the position of its major influx into the coal, near the paper burn line, cannot be seen on the contour diagrams during a puff. However, the oxygen influx during the puff leaves burnt-out channels in the coal which become evident at later stages in the smoking cycle.

When the puff ends, the product formation/transfer balance is interrupted, resulting in a local build-up of the product in its formation region. This local build-up reaches a maximum at $0.5-1.0$ seconds after the end of the puff, after which time diffusion processes deplete the level.

During the static smoulder period, distinct high and low temperature regions for the formation of carbon monoxide and dioxide are not evident inside the coal. However, towards the latter half of the puff, a distinct carbon dioxide formation region starts to appear behind the completely oxygen-deficient region. Application of the pyrolysis computer model, developed previously, confirms that this second region is a thermal decomposition region, and shows that such a region for carbon monoxide is not resolved from the combustion region.

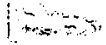

\section{ZUSAMMENFASSUNG}

In einer brennenden Cigarette wurde die Verteilung der Temperatur und der Konzentrationen an Kohlenmonoxid, Kohlendioxid, Wasserstoff, Propan und Sauerstoff zu aufeinanderfolgenden Zeitpunkten vor, während und nach Ablauf eines Zuges gemessen. Das Abrauchen erfolgte in einer Atmosphäre von 21 Vol.-0\% Sauerstoff in Argon. Die Gasproben wurden der Cigarette mittels einer kleinen Analysensonde entnommen, die über eine Filtriervorrichtung mit einem Quadrupolmassenspektrometer verbunden war.

Die Verteilungsprofile lassen die Komplexität der in der Glutzone stattfindenden Prozesse der Gasbildung und -bewegung und deren Veränderung während des $A b$ rauchvorganges erkennen. Im Inneren der Kohle befindet 
sich fast gar kein Sauerstoff. Dieser wird so schnell verbraucht, daß aus den Profildiagrammen während des Zuges nicht ersehen werden kann, an welcher Stelle nahe der Brennlinie des Papiers er in den Verkohlungsbereich hauptsächlich einströmt. Der während des Zuges eintretende Sauerstoff hinterläßt in der Glutzone jedoch Verbrennungskanäle, die später im Laufe der Zugperiode sidhtbar werden.

Wenn der Zug endet, wird das zwischen der Bildung der Gase und deren Obergang in den Rauch bestehende Gleichgewicht unterbrochen, wobei sich die Gase an ihrem Entstehungsort anreichern. Diese lokale Anreicherung erreicht 0,5-1,0 s nach Beendigung des Zuges ein Maximum, das sich danach durch Diffusionsprozesse abbaut.

Während des statischen Glimmintervalls sind im Glutzonenbereich in bezug auf die Kohlenmonoxid- und Kohlendioxidbildung keine bestimmten Zonen hoher und niedriger Temperatur erkennbar. In der zweiten Zughälfte zeigt sich jedoch deutlich, daß sich Kohlendioxid hinter der sauerstofffreien Region zu bilden beginnt. Auf der Basis des früher entwickelten Computer-Pyrolysemodells wird bestätigt, daß es sich dort um einen Bereich thermischer Zersetzung handelt, und es zeigt sich, daß dieser Bereich sich im Falle von Kohlenmonoxid von der Verbrennungsregion nidht abgrenzt.

\section{RESUME}

Les plages de distribution de la température des gaz et des concentrations de monoxide de carbone, de dioxide de carbone, d'hydrogène, de propane et d'oxygène ont été déterminées successivement avant, pendant et après une bouffée d'une cigarette en combustion. Le furnage a été effectué dans une atmosphère de $21 \%(\mathrm{v} / \mathrm{v})$ d'oxygène dans l'argon. Les prélèvements de gaz ont été faits au moyen d'une petite sonde, à travers un dispositif de filtrage, et analysés avec un spectromètre de masse quadripolaire.

Les zones de distribution mettent en évidence la complexité des processus de formation et de migration des gaz dans la braise, ainsi que de leur variation pendant le fumage. L'intérieur de la braise est presque entiàrement dépourvu d'oxygène. La consommation de l'oxygène est si rapide que l'endroit principal de sá pénétration dans la braise, près de la ligne de combustion du papier, n'est pas visible sur le diagramme de zones pendant la bouffée. Cependant, l'oxygène affluant pendant la bouffée laisse des canaux de combustion dans la braise qui sont visibles à un stade ultérieur du cycle de bouffée.

A la fin de la bouffée, l'équilibre entre la formation des produits et leur transfert dans la fumée est rompu, ce qui provoque leur accumulation dans la zone de formation. Cette accumulation atteint son maximum $0,5-1,0$ secondes après la fin de la bouffée, puis elle décroît par un processus de diffusion.

Durant la combustion libre, on n'observe pas, à l'intérieur de la braise, de zones distinctes de températures élevée et basse de formation de monoxide et de dioxide de carbone. Cependant, vers la seconde moitié de la bouffée, une zone distincte de formation de dioxide de carbone se met à apparaître à l'arrière de la zone dépourvue d'oxygène. Le modèle de pyrolyse simulée par ordinateur, mis au point précédemment, confirme que cette seconde zone est une zone de décomposition thermique, tandis que la région de formation du monoxide de carbone se confond avec la zone de combustion proprement dite.

\section{REFERENCES}

1. Baker, R. R., and K. D. Kilburn: The distribution of gases within the combustion coal of a cigarette; Beitr. Tabakforsch. 7 (1973) 79-87.

2. Baker, R. R.: Environmental conditions inside a burning cigarette, in: Analytical calorimetry, Vol. 4, edited by R. S. Porter and J. F. Johnson; Plenum Publishing Corporation, New York, 1977, pp. 193-202.

3. Baker, R. R.: Temperature variation within a cigarette combustion coal during the smoking cycle; High Temp. Science 7 (1975) 236-247.

4. Newsome, J. R., and C. H. Keith: Variation of the gas phase composition within a burning cigarette; Tobacco Science 9 (1965) 65-69.

5. Lanzillotti, H. V., and A. R. Wayte: One-dimensional gas concentration profiles within a burning cigarette during a puff; Beitr. Tabakforsch. 8 (1975) 219-224.

6. Encyclopaedia Britannica, Vol. 3, 1957, p. 272.

7. Giddings, J. C.: Dynamics of chromatography, Part 1: Principles and theory; Marcel Dekker, New York, 1965, pp. 26-33.

8. Fuller, E. N., P. D. Schettler and J. C. Giddings: A new method for prediction of binary gas-phase diffusion coefficients; Ind. and Eng. Chem., Ind./Int. Edn. 58 (5) (1966) 19-27.

9. Neurath, G., H. Ehmke and H. Sodneemann: Uber den Wassergehalt von Haupt- und Nebenstromrauch; Beitr. Tabakforsch. 3 (1966) 351-357.

10. Baker, R. R.: Unpublished results.

11. Baker, R. R.: Gas velocities inside a burning cigarette; Nature 264 (1976) 167-169.

12. Egerton, Sir A., K. Gugan and F. J. Weinberg: The mechanism of smouldering in cigarettes; Combust. Flame 7 (1963) 63-78.

13. Gugan, K.: Natural smoulder in cigarettes; Combust. Flame 10 (1966) 161-164.

14. Baker, R. R.: The kinetics of tobacco pyrolysis; Thermochim. Acta 17 (1976) 29-63.

15. Baxter, J. E., and M. E. Hobbs: Investigation of some physico-dhemical aspects of cigarette smoke using oxygen isotopes, 1 . $\mathrm{CO}$ and $\mathrm{CO}_{2}$ from atmospheric oxidation; Tobacco Science 11 (1967) 65-71. 
16. Johnson, W. R., D. H. Powell, R. W. Hale and R. A. Kornfeld: Incorporation of atmospheric oxygen into components of cigarette smoke; Chem. Ind. (London) 1975, 521-522.

17. Kornfeld, R. A., R. H. Newman, L. E. Brown, Jr., and W. R. Johnson, Jr.: $\mathrm{H}_{2} \mathrm{O}^{18}$-cigarette smoke gas phase interaction; Chem. Ind. (London) 1979, 664-666.

18. Baker, R. R.: Combustion and thermal decomposition regions inside a burning cigarette; Combust. Flame 30 (1977) 21-32.

19. Baker, R. R.: Kinetic mechanism of the thermal decomposition of tobacco; Thermochim. Acta 28 (1979) $45-57$.
Adknowledgements

The technical assistance of Mr. B. G. Bunn, computing assistance of Mr.J. M. Davey and belpful discussions with Dr. K. D. Kilburn are gratefully adknowledged.

Author's address:

Group Research and Development Centre, British-American Tobacco Co. Ltd.,

Regent's Park Road, Southampton, SO9 1 PE,

England. 